\begin{tabular}{|l|l|}
\hline Asian Journal of Pharmaceutical Research & $\mathbf{A}$ \\
and Development & $\mathbf{J}$ \\
$\begin{array}{l}\text { (An International Peer-Reviewed Journal of Pharmaceutical Research and Development) } \\
\text { @ 2013-18, publisher and licensee AJPRD, This is an Open Access article which permits unrestricted } \\
\text { non-commercial use, provided the original work is properly cited }\end{array}$ & $\mathbf{P}$ \\
\hline
\end{tabular}

Open $\odot$ Access

Available online at http://ajprd.com/index.php

Research Article

\title{
ISOLATION AND INVESTIGATION OF \\ PHYTOCHEMICALS AND PHARMACOLOGICAL SCREENING OF TAGETES ERECTA L. LEAVES EXTRACT
}

\author{
Thorat Kranti Jayavant*, P.J. Shirote, Aparna Shivaji Kadam, Bhavna Deshmane, Karade \\ Dhanashree R., Yamgar Tejaswini S., Patil Nivedita H
}

Department of Pharmaceutical Chemistry, Appasaheb Birnale College of Pharmacy, South Shivajinagar, Miraj Road, Sangli, Maharashtra, India. 416416.

\begin{abstract}
Extraction and isolation of plant constituents plays an important role as a therapeutic remedy. Isolation of active plant constituents helps in developing lead molecule in drug development process. Aim of present study is to extract, isolate plant constituents and spectral and pharmacological investigation. The major advantage of herbal drugs to synthetic drugs is that they produce more therapeutic effect and fewer side effects. Herbal drugs also have potential in drug development by generating a lead molecule which helps in designing of synthetic drugs. Tagetes species belonging to family Asteraceae, are most common in plant kingdom, which is used in different areas like cosmetic preparation, medicines as well as it is most commonly used as ornamentals. Flowers are mainly used for all these purposes by using extraction process. Tagetes species contains mainly lutien such as carotenoids or xanthophylls containing two cyclic end groups and basic C-40 isoprene unit. The leaves are reported to possess wound healing, antiulcer, muscular pain relief activities10. The basic criteria of present work are to isolate the active plant constituents from these plants and to avail about its anticancer activity on cancer cell line
\end{abstract}

Keywords: Extraction, Tagetes species, anticancer, cancer cell line..

Article Info: Received 25 July, 2018;

Review Completed 14 Aug 2018;

Accepted 18 Aug 2018

Cite this article as:

Thorat Kranti Jayavant, Isolation And Investigation Of Phytochemicals And Pharmacological Screening Of Tagetes Erecta L. Leaves Extract, Asian Journal of Pharmaceutical research and Development.2018;6 (4): 39-44

DOI: http://dx.doi.org/10.22270/ajprd.v6.i4.360

*Address for Correspondence

Kranti Jayavan Thorat Department of Pharmaceutical Chemistry,Appasaheb Birnale College of Pharmacy, South Shivajinagar, Miraj Road, Sangli, Maharashtra, India.

\section{INTRODUCTION:}

$\mathrm{W}$ orld Health Organization has set precise guidelines for the evaluation of the safety, efficacy, and quality of herbal medicines. Herbal drug is a chief constituent in traditional medicine and a common constituent in Ayurvedic, homeopathic, naturopathic and other medicine systems. Herbs are usually considered as safe since they belong to natural sources. The use of herbal drugs due to toxicity and side effects of allopathic medicines, has led to rapid increase in the number of herbal drug manufacturers. ${ }^{(1)}$

Tagetes erecta, the Mexican marigold, also called Aztec marigold, is a species of the genus Tagetes native to Mexico and Central America. Despite its being native to the Americas, it is often called African marigold. It belongs to family Asteraceae. Marigold plants are stout and branching and can grow up to $60 \mathrm{~cm}$ tall. They are cultivated all over the world for their decorative and ornamental flowers. Leaves - finely segmented and fernlike, they are dark green in color and are strongly scented. Flowers - vary in color from yellow and gold to orange, red and mahogany. The taller and largerflowered Tagetes erecta was often called African marigold and the smaller Tagetes patula was known as French marigold. But marigolds have been cultivated all over the world and lots of similar hybrid varieties have been developed from the two species. Working out which species is which isn't easy, and some botanists even believe they are the same species. ${ }^{(2)}$ It has many 
uses. It is used for anemia, irregular menstruation, abdominal pain during menstrual period, rheumatic muscular and bone pain.

The objectives of the present work are to extract the plant material with suitable solvent. Then physicochemical and phytochemical study is carried out to isolate the active constituent from the plant extract. These active constituents are allowed to spectroscopic analysis for structural elucidation.

\section{MATERIALS AND METHODS:}

The leaves of Tagetes erecta were collected from farm of marigold in Satara region in the month of October 2012. Authentication of leaves of Tagetes erecta was done by Prof. Vadmare, Botanist, Department of Botany Kasturbai Walchand College, Sangli.

\section{Extraction of Tagetes erecta L. leaves:}

The leaves of Tagetes erecta were dried and powdered by mixer grinder to obtain coarse powder. This power was defatted by petroleum ether. Extraction was carried out from this defatted powder of Tagetes erecta with methanol as a solvent using soxhlet extraction process. Five repeated cycles of extraction were carried out. Dark green sticky extract was obtained which further evaporated to dryness.

\section{Phytochemical study of extract:}

The methanol extract of Tagetes erecta leaves were subjected to qualitative chemical investigation to check the presence of various chemical constituents in the extract. Following tests were carried out-

Table no.1 - Phytochemical study of Tagetes erecta L. extract:

\begin{tabular}{|c|c|c|}
\hline $\begin{array}{l}\text { Sr. } \\
\text { no. }\end{array}$ & Test & Observation \\
\hline \multirow[t]{4}{*}{1.} & $\begin{array}{l}\text { Tests for alkaloids: } \\
\text { Mayer's test }\end{array}$ & $\begin{array}{l}\text { Test gives cream } \\
\text { colored precipitate. }\end{array}$ \\
\hline & Wagner's test & Brown precipitate. \\
\hline & Hager's test & Yellow precipitate. \\
\hline & Dragendorff's test & $\begin{array}{l}\text { Reddish brown } \\
\text { precipitate. }\end{array}$ \\
\hline \multirow[t]{2}{*}{2.} & $\begin{array}{l}\text { Tests for flavonoids: } \\
\text { Shinoda's test }\end{array}$ & Pink to magneta red. \\
\hline & $\mathrm{FeCl} 3$ test & No colour. \\
\hline \multirow[t]{3}{*}{3.} & $\begin{array}{l}\text { Tests for steroids: } \\
\text { Salkowaski test }\end{array}$ & $\begin{array}{l}\text { Chloroform layer } \\
\text { appears red and acid } \\
\text { layer shows greenish } \\
\text { yellow fluorescence. }\end{array}$ \\
\hline & $\begin{array}{l}\text { Liebermann Burchard } \\
\text { test }\end{array}$ & $\begin{array}{l}\text { First red, then blue and } \\
\text { finally green color } \\
\text { appeared. }\end{array}$ \\
\hline & $\begin{array}{l}\text { Liebermann Burchard } \\
\text { reaction }\end{array}$ & Blue color appears \\
\hline \multirow[t]{2}{*}{4.} & $\begin{array}{l}\text { Test for Phenolic } \\
\text { acid and tannins: } \\
5 \% \text { Ferric chloride test }\end{array}$ & $\begin{array}{l}\text { Dark colored solution } \\
\text { obtained }\end{array}$ \\
\hline & Lead acetate test & $\begin{array}{l}\text { Yellow color } \\
\text { precipitate obtained }\end{array}$ \\
\hline
\end{tabular}

\section{Determination of Total Ash value:}

- A crucible was weighed and ignited.

- 2 gm of mucilage powder was weighed and taken in crucible.

- Incinerated the crucible at a temperature not exceeding 450oc in Muffle furnace.

- Crucible was cooled in desiccator.

- Procedure was repeated until it became white up to constant weight.

- Calculated the percentage of ash with reference to air dried drug.

- Total Ash $=100 / \mathrm{Y} \times(\mathrm{y})$

Where: Y- Weight of powder taken in gm

$\mathrm{y}$ - Weight of ash in gm

\section{Determination of Acid- insoluble Ash:}

- Total ash obtained as previous step boiled for $5 \mathrm{~min}$ with $25 \mathrm{~mL}$ dil. $\mathrm{HCl}$ in $100 \mathrm{ml}$ beaker.

- Collected the insoluble matter then washed with hot water.

- Ignited to constant weight.

- Calculated the percent of acid - insoluble ash with reference to air dried drug.

Acid- insoluble Ash = 100/Y $\times(y)$

Where: Y-Weight of insoluble matter taken in gm

$\mathrm{y}$ - Weight of ash in gm

\section{Determination of Water soluble Ash:}

- Total ash obtained as previous step boiled for $5 \mathrm{~min}$ with $25 \mathrm{~mL}$ water in $100 \mathrm{ml}$ beaker.

- Collected the insoluble matter then washed with hot water.

- Ignited to constant weight.

- Calculated the percent of Water soluble Ash with reference to air dried drug.

\section{Determination of Moisture content:}

- Taken 2gm sample in tarred Petri dish and was placed in an oven.

- Drying of sample was carried out at $105^{\circ} \mathrm{C}$ until a constant weight of the sample was observed. ${ }^{(3)}$

$\%$ moisture content $=100 / \mathrm{Y} \times(\mathrm{y})$

Where: Y-Weight of powder taken in gm

$\mathrm{y}-$ Weight of powder after constant drying in $\mathrm{gm}$

Identification, separation and isolation of active plant constituents:

The separation of plant constituents was carried out using different chromatographic techniques such as thin layer chromatography, column chromatography etc. The choice of technique depends largely on the solubility properties and volatilities of the compounds to be separated. Separation techniques are important and applied in phytochemical research.Various mobile phases were tried for separation of different constituent from methanol extract of Tagetes erecta Linn. Benzene: Chloroform: Ethanol $(2: 4: 4)$ gives four different spots on TLC plate which are clearly resolved. 
In column chromatography, a vertical glass column was used in which the mobile phase, Benzene: chloroform: Ethanol (2:4:4) was added. The stationary phase, a solid adsorbent i.e. crystalline silica gel 60-1200, was added in the column with continuous tapping on the column, so as to prevent air gaps in it. The silica gel was added such that some solvent was remaining on it i.e. below the $1 \mathrm{~cm}$ from the solvent meniscus. Then solvent system was added till the neck of the column, and was packed properly and kept for saturation. Then the solvent in the column was eluted up to level of silica gel and to the top of it concentrated extract was added, the solvent was eluted so that extract was adsorbed properly on silica. The solvent system was added with the help of glass rod so that the column was not disturbed. The solvent was eluted drop wise, such that 4-6 drops per minute so that better resolution was obtained. Three bands obtained was eluted and stored in desiccators. ${ }^{(4,5)}$

\section{Spectroscopic analysis:}

Infra-red spectroscopy - The bands isolated from the column chromatography were taken; the solvent was evaporated and dried in desiccators so as to get dry powder. The dried compound mixed with $\mathrm{KBr}$ and pellet was prepared using $\mathrm{KBr}$ press and an IR spectrum was carried out using Jasco FTIR at A.B.C.P., Sangli.

NMR spectroscopy - The isolated, dried compounds were subjected to NMR spectroscopic analysis. The compounds were soluble in $\mathrm{CDCL}_{3}$. The NMR was performed at Vishnu chemicals, Hyderabad. The chemical shift data obtained were expressed as $\delta$ value.

GC-MS spectroscopy - The compounds isolated from column chromatography were subjected to GC-MS analysis by dissolving it in methanol. From the mass spectrum the molecular formula of the compound was obtained, which has important role in the identification of the compound. The GC-MS spectroscopy was performed at analytical department of Shivaji
University, Kolhapur. The instrument used was GCMS QP 2010-Shimadzu for analysis. ${ }^{(6-9)}$

\section{RESULT AND DISCUSSION:}

\section{Extractive value of Tagetes erecta Linn:}

Table no.2- Extractive value of Tagetes erecta Linn.

\begin{tabular}{|l|l|l|}
\hline Plant name & $\begin{array}{l}\text { Extract } \\
\text { obtained (gm) }\end{array}$ & $\begin{array}{l}\text { \% } \\
\text { Extractive } \\
\text { value }\end{array}$ \\
\hline $\begin{array}{l}\text { Tagetes } \\
\text { erecta Linn }\end{array}$ & 32.5 & 10.83 \\
\hline
\end{tabular}

\section{Physicochemical evaluation of Tagetes erecta Linn.:}

Table no.3 - Ash value of extract of Tagetes erecta Linn.

\begin{tabular}{|l|l|l|}
\hline $\begin{array}{l}\text { Sr. } \\
\text { No. }\end{array}$ & Ash value (\%) & $\begin{array}{l}\text { Tagetes erecta } \\
\text { Linn }\end{array}$ \\
\hline 1 & Total ash & $11.98 \pm 0.001 \%$ \\
\hline 2 & $\begin{array}{l}\text { Acid insoluble } \\
\text { ash }\end{array}$ & $3.16 \pm 0.001 \%$ \\
\hline 3 & $\begin{array}{l}\text { Water soluble } \\
\text { ash }\end{array}$ & $3.53 \pm 0.002 \%$ \\
\hline
\end{tabular}

Rf value of isolated spot:

Table no.4 - Rf value of isolated compounds of Tagetes erecta Linn.extract

\begin{tabular}{|l|l|l|}
\hline Sr. no. & Isolated compounds & Rf value \\
\hline 1 & AK1 & 0.96 \\
\hline 2 & AK2 & 0.78 \\
\hline 3 & AK3 & 0.46 \\
\hline
\end{tabular}

\section{Phytochemical evaluation of isolated compound:}

Table no. 5 - Phytochemical tests for isolated compounds of Tagetes erecta L. extract.:

\begin{tabular}{|l|l|l|l|}
\hline Sr. no. & Isolated compounds & Test & Observation \\
\hline \multirow{4}{*}{1} & \multirow{4}{*}{ AK1 and AK2 } & $\begin{array}{l}\text { Test for Steroids: } \\
\text { Salkowaski test }\end{array}$ & + \\
\cline { 3 - 4 } & & Libermann Burchard test & + \\
\cline { 3 - 4 } 2 & Libermann Burchard reaction- & + \\
\hline \multirow{3}{*}{2} & AK3 & $\begin{array}{l}\text { Test for Phenolic acids and } \\
\text { tannins: } \\
5 \% \text { FeCl3 test }\end{array}$ & + \\
\cline { 3 - 4 } & Lead acetate test & + \\
\hline
\end{tabular}

Melting point of isolated compound:

Table no. 6 - Melting point of isolated compounds of Tagetes erecta L. extract.

\begin{tabular}{|l|l|l|}
\hline Sr. no. & $\begin{array}{l}\text { Isolated } \\
\text { compound }\end{array}$ & $\begin{array}{l}\text { Melting } \\
\text { point }\left({ }^{\mathbf{0}} \mathbf{C}\right)\end{array}$ \\
\hline 1 & AK1 & 160 \\
\hline 2 & AK2 & 136 \\
\hline 3 & AK3 & 157 \\
\hline
\end{tabular}

Spectral analysis of isolated compounds of Tagetes erecta Linn.

Table no. 7 - IR interpretation of AK1 compound.

\begin{tabular}{|l|l|l|}
\hline Sr. no. & Peak $\left(\mathbf{c m}^{-\mathbf{1}}\right)$ & Indication \\
\hline 1 & 3404.71 & $-\mathrm{OH}$ \\
\hline 2 & 2924.52 & $\mathrm{C}-\mathrm{H}$ str. \\
\hline 3 & 1743.33 & $\mathrm{C}=\mathrm{O}$ str. \\
\hline 4 & 1583.27 & $\mathrm{C}=\mathrm{C}$ str. \\
\hline
\end{tabular}


AK3 compound:

Table no. 8 - IR interpretation of AK3 compound.

\begin{tabular}{|l|l|l|}
\hline Sr. no. & Peak $\left(\mathbf{c m}^{-1}\right)$ & Indication \\
\hline 1 & 3413.39 & $-\mathrm{OH}$ \\
\hline 2 & $3152.08,3110.62$ & $\begin{array}{l}\text { C-H str. } \\
\text { Aromatic rings }\end{array}$ \\
\hline 3 & 1717.30 & $\mathrm{C}=\mathrm{O}$ str. \\
\hline 4 & $1575.56,1558.20$ & $\begin{array}{l}\mathrm{C}=\mathrm{C} \\
\text { Aromatic rings }\end{array}$ \\
\hline
\end{tabular}

\section{NMR spectral data:}

AK1 compound:

Table no.9 - NMR interpretation of AK1 compound.

\begin{tabular}{|l|l|l|}
\hline $\begin{array}{l}\text { Sr. } \\
\text { no. }\end{array}$ & Value ( $\boldsymbol{\delta}$ ppm) & Indication \\
\hline 1 & 5.36 & Vinylic proton \\
\hline 2 & $3.69,3.66$ & Alcohol-OH \\
\hline 3 & 1.68 & R-O-H \\
\hline 4 & 1.25 & R2CH2 \\
\hline
\end{tabular}

AK3 compound:

\section{GC-MS spectral data:}

Table no. 10 - NMR interpretation of AK3 compound.

\begin{tabular}{|l|l|l|}
\hline Sr. no. & Value ( $\mathbf{p p m})$ & Indication \\
\hline 1 & 4.35 & Ar-O-H \\
\hline 2 & $3.69,3.66$ & Alcohol-OH \\
\hline 3 & 1.68 & R-O-H \\
\hline 4 & 1.24 & $\mathrm{R}_{2} \mathrm{CH}_{2}$ \\
\hline
\end{tabular}

AK1 compound-

Table no. 11 - GCMS interpretation of AK1 compound

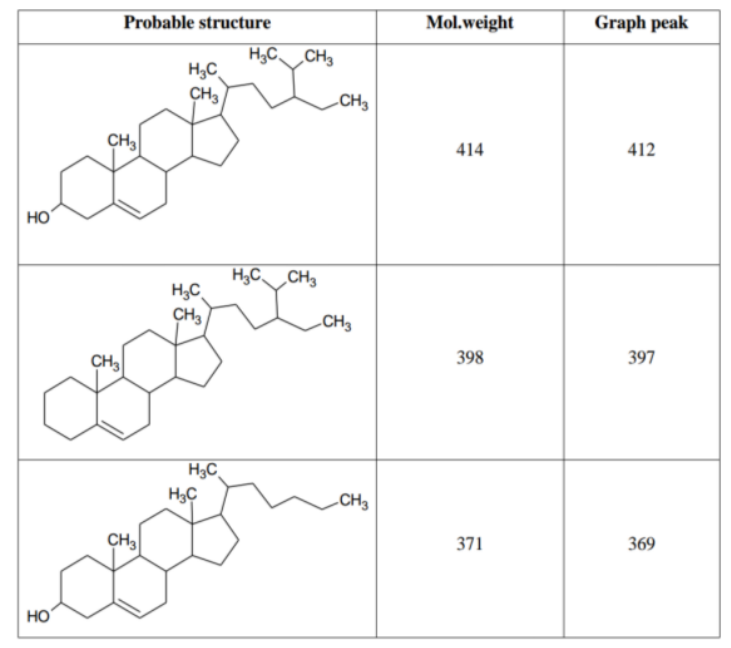

\begin{tabular}{|l|l|l|}
\hline & 273 \\
\hline
\end{tabular}


AK3 compound-

Table no. 12 - GCMS interpretation of AK3 compound

\begin{tabular}{|l|c|c|}
\hline Probable structure & Mol. Weight & Peak graph \\
\hline & & 278 \\
\hline \\
\hline
\end{tabular}

\section{Structure elucidation-}

According to the data obtained by IR, NMR and GCMS of $\mathrm{AK} 1$ and $\mathrm{AK} 3$ compounds there might be present of following phytochemicals.

\section{AK1 compound-}

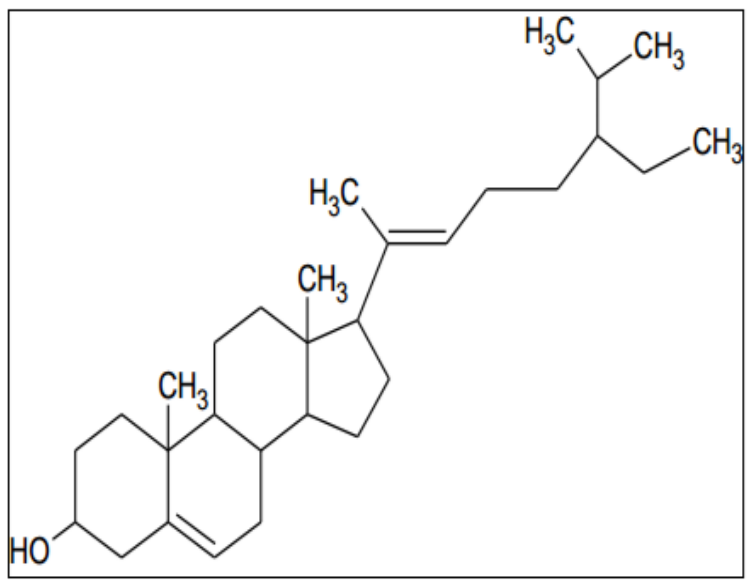

Fig.1 - Structure of Stigmasterol.

AK3 compound-

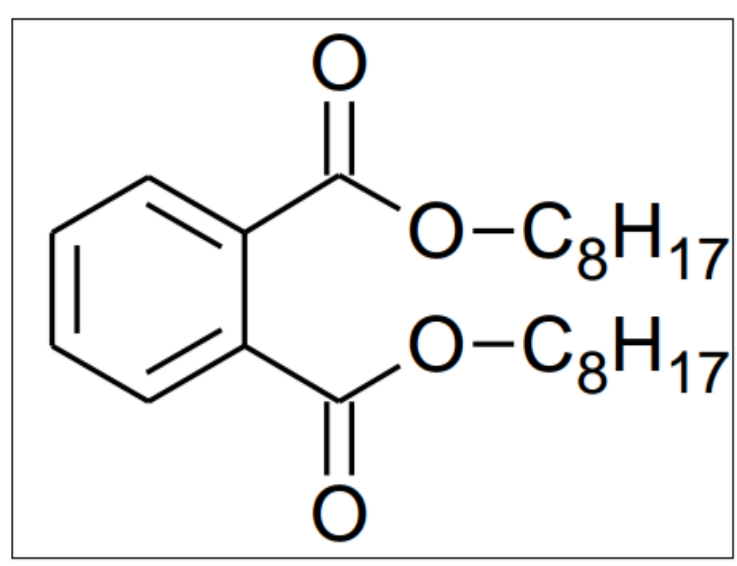

Fig.2 - Structure of 1,2-Benzenedicarboxylic acid, Dissoctyl ester.

\section{Result of In-vitro Antioxidant activity:}

In-vitro antioxidant activity of Tagetes erecta L. leaves extract and its isolated compounds i.e. AK1, AK2 and AK3 was carried out. Two different in-vitro Antioxidant assays were carried out namely; Hydrogen peroxide $(\mathrm{H} 2 \mathrm{O} 2)$ radical scavenging antioxidant assay and Hydroxyl ion $(\mathrm{OH})$ scavenging assay. Ascorbic acid was used as a standard.

Hydrogen peroxide $\left(\mathrm{H}_{2} \mathrm{O}_{2}\right)$ radical scavenging antioxidant assay:

Table no. $13-\mathrm{H}_{2} \mathrm{O}_{2}$ radical scavenging activity of Tagetes erecta $\mathrm{L}$. extract and its isolated compounds

\begin{tabular}{|l|l|l|}
\hline Sr. no. & Compound & Absorbance(230nm) \\
\hline 1 & $\begin{array}{l}\text { Ascorbic acid } \\
\text { (std) }\end{array}$ & 0.1024 \\
\hline 2 & AK1 & 0.2062 \\
\hline 3 & AK2 & 0.2183 \\
\hline 4 & AK3 & 0.1537 \\
\hline 5 & AK4 & 0.3052 \\
\hline
\end{tabular}

Table no. $14-\mathrm{H}_{2} \mathrm{O}_{2}$ radical scavenging activity of Tagetes erecta L. extract and its isolated compounds in percentage

\begin{tabular}{|l|l|l|}
\hline $\begin{array}{l}\text { Sr. } \\
\text { no. }\end{array}$ & Compound & $\begin{array}{l}\text { \% Radical } \\
\text { scavenging activity }\end{array}$ \\
\hline 1 & Ascorbic acid (std) & 85.5 \\
\hline 2 & AK1 & 74.70 \\
\hline 3 & AK2 & 66.89 \\
\hline 4 & AK3 & 80.16 \\
\hline 5 & AK4 & 64.40 \\
\hline
\end{tabular}


Where, AK1 - First isolated compound (steroid),

AK2- second isolated compound (steroid),

AK3- Third isolated compound (phenolic acid),

AK4- Whole extract.

According to the data obtained it was concluded that AK3 compound showed highest Antioxidant activity among all isolated compounds and whole extract. Ascorbic acid which was used as a standard showed $85.5 \%$ while AK3 compound showed $80.16 \%$ radical scavenging activity.

\section{Result of In-vitro anticancer activity:}

In-vitro cytotoxicity study was carried out on MCF-7 cell line. Procedure of MTT assay was used.

$\%$ cell viability- $77.70 \%$

Viable cells/ml- 3.66X10 $0^{4}$

Table no. 15 - In-vitro anticancer activity of Tagetes erecta $\mathrm{L}$. extract and its isolated compounds in percentage.

\begin{tabular}{|l|l|l|}
\hline $\begin{array}{l}\text { Sr. } \\
\text { no. }\end{array}$ & Compound & $\begin{array}{l}\text { \% Growth } \\
\text { inhibition }\end{array}$ \\
\hline 1 & Temoxifen(std) & 40.11 \\
\hline 2 & AK1 & 44.38 \\
\hline 3 & AK2 & 32.58 \\
\hline 4 & AK3 & 25.05 \\
\hline 5 & AK4 & 37.05 \\
\hline
\end{tabular}

In-vitro anticancer activity of extract of Tagetes erecta L. and its isolated compound was carried out on MCF-7 cell line. Compound AK1 showed highest \% growth inhibition of cancer cells among all other compounds and standard drug i.e. Temoxifen. AK1 compound

\section{REFERENCES:}

1. Bodhisattwa M, Nagori BP, Rambir S, et al. Recent trends in herbal drugs: A review. International Journal of Drug Research and Technology. 2011;1(1):17-25.

2. Health and Fitness Articles; www.articaldoctor.com

3. Pulok K. Mukherjee, Quality control of Herbal Drugs, An approach to Evaluation of Botanicals, Business Horizons, First edition 2002; 445-454.

4. Column chromatography.html.doc.

5. Column chromatography, CU Boulder Organic Chemistry undergraduate Course, Lab Techniques.

6. William Kemp, Organic spectroscopy, Palgrave publishers, 3rd edition; p. 60, 62, 66, 173-175.

7. Silverstein, Webster, Spectrometric identification of organic compounds, 6th edition, John Wiley and sons, Inc.; p 136-140. showed $44.38 \%$ and standard drug Temoxifen showed $40.11 \%$ growth inhibition of cancer cells. All other compounds also showed good $\%$ growth inhibition of cancer cells.

From the result obtained from in-vitro antioxidant activity and in0vitro anticancer activity it was observed that the methanol extract of Tagetes erecta and its isolated fractions possess antioxidant and anticancer activity.

\section{CONCLUSION:}

Natural products from plant, animal and minerals have been the basis of the treatment of human disease. Medicinal plants play an important role in the development of potent therapeutic agents. Extraction was done using methanol. Physicochemical and phytochemical tests for Tagetes erecta leaves extract were carried out. Isolation of steroids and phenolic acid was obtained using column chromatography. Spectral analysis of isolated compound was carried out pharmacological screening such as In vitro antioxidant assay and anticancer assay was done. The standardization parameters, TLC and Column Chromatography profiles were used for deciding the identity and purity of herbal extract. Chromatographic and spectroscopic techniques proved its usefulness in isolation and proper identification of sterols and phenolic acid. Two compounds i.e.; Stigmasterol and 1, 2-Benzenedicarboxylic acid, dissoctyl ester may be the possible structure of isolated compounds of extract. $\mathrm{H} 2 \mathrm{O} 2$ radical scavenging activity of $3 \mathrm{rd}$ isolated compound i.e.; Phenolic acid showed highest activity among these entire isolated compound. -OH radical scavenging activity of $3^{\text {rd }}$ isolated compound i.e.; Phenolic acid showed highest activity among these entire isolated compound. $1^{\text {st }}$ isolated compound i.e.; Sterol showed maximum $\%$ growth inhibition of MCF-7 cancer cells.

8. Chatwal, Anand, Instrumental methods of chemical analysis, Himalaya publishing house, 5th edition; p. 2.62$2.68,2.213-2.225$.

9. John R. Dyer, Applications of absorption spectroscopy of organic compounds, Oct.2002; p. 84-85.

10. Rajamanikandan S, Thangaraj S, Durgapriya D, et al. Radical scavenging and antioxidant activity of ethanolic extract of Mollugo nudicaulis by In vitro assays. Indian Journal of Pharmaceutical Education \& Research. 2011;45(4):310-316.

11. Zakaria ZA, Mohamed AM, Mohd Jamil NS, et al. In vitro cytotoxic and antioxidant properties of the aqueous, chloroform and methanol extracts of Dicranopteris linearis leaves. African Journal of Biotechnology. 2011;(2):273-282. 